\title{
Comparative Identification of Mycobacterium bovis By Using A Serological ELISA (IDEXX) and Tuberculin Test in Cattle in Wasit Province /Iraq
}

\author{
Hala SR. AL-Taee \\ College of Veterinary Medicine, University of Wasit
}

\begin{abstract}
In Iraq, due to semi-full-scale dependence on tuberculin test, and presence, only, limited serological and molecular studies, the practical Mycobacterium bovis infection rate still dispersed especially in Wasit province that consider as an endemic area for bovine tuberculosis. In this study, two diagnostic techniques were used, IDEXX ELISA and tuberculin test; 186 cattle (155 females and 31 males), selected randomly and divided into two age groups, the first with less than 5 years and the second with more than 5 years. All cattle submitted to both tests and the results showed that $(9.13 \%)$ were positives for tuberculin test and $(17.2 \%)$ for IDEXX ELISA. Also, in age groups, the result of $<5$ years group by tuberculin test was $5.04 \%$, and $11.76 \%$ by IDEXX ELISA test; while in $>5$ years group, was $16.41 \%$ and $26.86 \%$, by tuberculin test and IDEXX ELISA test, respectively. Significant, the statistical different, $\mathrm{P} \leq 0.05$, was reported through the positive results of both tests as well as the two age groups, while in sex groups, the variance had not shown through both sexes.
\end{abstract}

Keywords: Mycobacterium bovis, IDEXX ELISA, Tuberculin test, Cattle, Wasit province 
المقارن للابقار المصابة بعصيات السل البقري باستخدام اختبار الاليزا وإختبار السلين في ابقار محافظة واسط / العرلق

حلا سعيد رشيد الطائي

كلية الطب البيطري / جامعة واسط

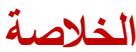

نتيجة للاعتماد شبه الكامل في العراق على اختبار السلين ووجود عدد محدود من الدراسات السبرولوجية

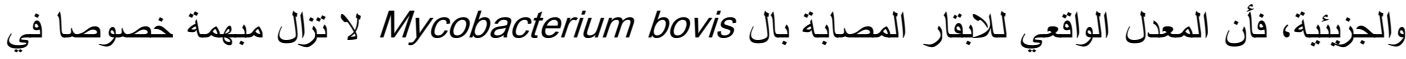
محافظة واسط التي تعتبر كمنطقة مسوبوءة لداء السل البقري • في هذه الدراسة ، تم استخدام اثثين من الثنال

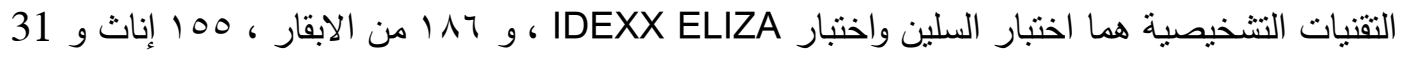

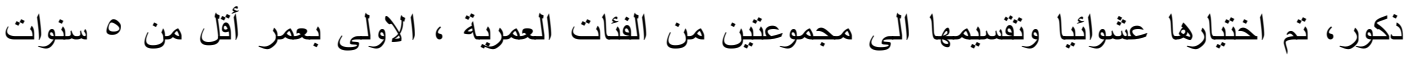

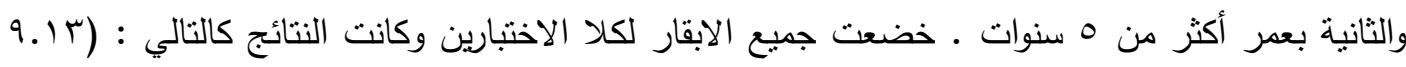

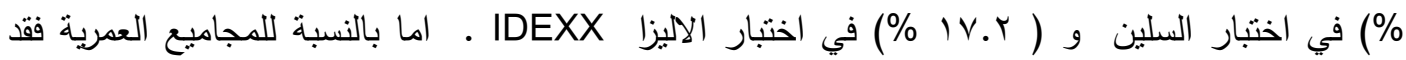

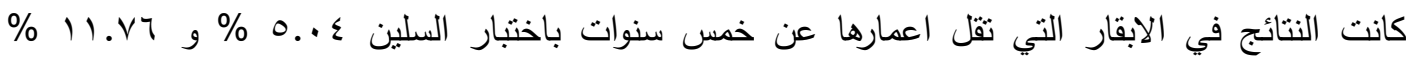

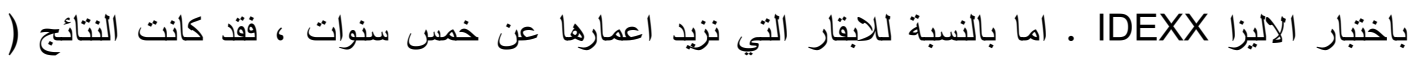

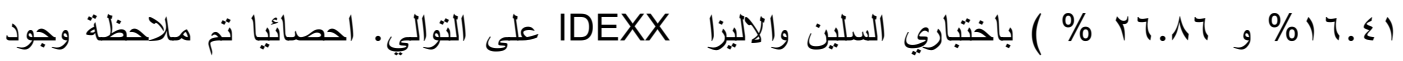

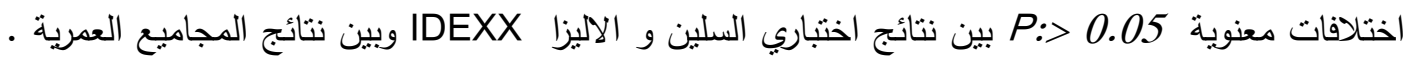
بالاعتماد على جنس الابقار ، لم تتم ملاحظة وجود فرق معنوي 0.05 >:P بين الذكور والاناث في معدل

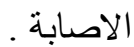




\section{Introduction}

Mycobacterium bovis, a classical pathological causer of tuberculosis in cattle, is an aerobic, non-motile, acid fast, slowly growing, non-photochromogenic bacterium that affined to the family of Mycobacteriaceae $(\mathbf{1}, \mathbf{2})$. Bovine tuberculosis (BTB) considers as serious and chronic infection which afflicted a large scale of animals such as cattle, camel, goat, deer, pigs, bison, domestic cats, foxes and rarely, sheep, horses and elephants $(3,4,5)$. Its worldwide distribution in most countries involving Iraq, although, several epidemiological and public health features of disease were stay, extremely, obscure $(6,7)$. Steele (1995) reported that $M$. bovis could result nearly 50 million infections worldwide resulting economically in large losses of nearly 3 billion dollars yearly (8). In Latin-America, BTB was accountable for nearly $2 \%$ and $8 \%$ of recently human pulmonary and extrapulmonary tuberculosis focuses (9). In Asia, 94\% of total cows and less than $99 \%$ of total buffaloes were be existence in regions had BTB with partial control or without it exposing a humanly human populations at risk in areas where these animals without or with only limited BTB control (10). WHO (2013) and Abdul sahib et al (2015) reported that Iraq was represented an elevated BTB rises region in Eastern Mediterranean region $(11,12)$. Recently, the increasing in attentions for BTB is focused to founding new methods for identifying the actual herd schemes that could be impressed with hazards of infection transition (3). "Although tuberculin skin test has been a hallmark of BTB eradication programs but it lacks to the required sensitivity, not efficient in detecting the disease at its different stages particularly at early and advanced ages, and can be confounded by exposure to nontuberculous mycobacteria as well as Fasciola hepatica, and cannot be repeated for 60 days due to desensitization " $(13, \mathbf{1 4})$. For controlling on those obstacles, several diagnostic methods are obtained to improve a predictive value of tuberculin skin such as the cellular immunoassay of gamma interferon, ELISA and PCR besides to bacteriological, histopathological and necropsy techniques $(\mathbf{1 5}, \mathbf{1 6})$. The antibodies that responses to $M$. bovis have been shown to be positives in correlation with mycobacterium emerged as pathogenesis and antigens overburden (17). However, the continuous development of serological tests provided a high degree in diagnosis of BTB and became as an integral to other tuberculin diagnosing methods (18). In addition, the application of multiple tests will gain more diagnostic accuracy through detecting of subsidiary infections that negative by tuberculin skin test (19). IDEXX $M$. bovis antibody kit (USA) is a new commercial ELISA test that manufactured by IDEXX Laboratories for the diagnosis of BTB, and could 
improve BTB detection because it's easy, cost effective for surveillance, need a few of time $(\mathbf{1 5}, \mathbf{2 0})$. It was validated and certified by the World Organization of Animal Health (OIE) in 2012 at approval number of 20120107 (21). In Iraq, all surveillance or control programs as well as the academic studies were depended on tuberculin test as the only method in detection of BTB. Therefore, the goals were to:

1. Detect the most actual and practical incidence rate of BTB in cattle of Wasit province by using two methods (skin test and IDEXX ELISA test).

2. Assessment the efficacy of IDEXX ELISA test that used for first in Iraq in detection of the specific antibodies against Mycobacterium bovis.

3. Comparison the positive results between the two age groups and between both sexes through depending on the results of both selected tests.

\section{Materials and method}

\section{Study's areas, animals and specimens collection}

During the first three months / 2016, the study was performed in rural areas of Wasit province / Iraq, involved (186) apparently healthy cattle that selected randomly from both sexes (155 females and 31 males), and divided into two age groups (less than 5 years and more than 5 years). From each one, $5 \mathrm{ml}$ of blood was collected under aseptic condition with using a disposable syringe that installed in the numbered without anti-coagulant tubes for serological diagnosis (22).

\section{Skin test or the Single Intradermal Comparative Cervical Test (SICCT)}

OIE prescribed the skin tuberculin test for BTB diagnosis throughout the intradermal utilization of purified protein derivatives (PPD) in field diagnostics. An increasing of skin fold thickness (>4 mm) was mean positive, (1-4 mm) doubtful and negative if ( $<1 \mathrm{~mm})$ (23). 


\section{IDEXX ELISA}

Bovine serums were examined through using an indirect IDEXX ELISA kit (USA) for bovine tuberculosis (Mycobacterium bovis) according to the manufacturer's instructions (IDEXX laboratories) that recommended the cut-off with S/P ratio of 0.3 . The $\mathrm{S} / \mathrm{P}$ ratio of $\geq 0.3$ was considered as the test had been positive.

\section{Statistical Analysis}

All data submitted to IBM SPSS v.23.program for statistical analysis. The efficiency of SICCT was validated against an IDEXX ELISA test that used as a gold standard. The positive associations were verified by Chi-square test with a level of $\mathrm{P} \leq 0.05$ (24).

\section{Results and Discussion}

The incidence of BTB had been observed to be increasing in several regions of the world whereas the living's measures is weak particularly in Asia and Africa as a result of absence the regular practical method for effective screening (25). Although, the skin test and culture are available for diagnosis of tuberculosis in animals or humans, but the serological techniques promised and provided a high sensitivity and specificity results in detection of infection (26). The results of this study revealed that the positive BTB with SICCT and IDEXX ELISA test were $17 / 186(9.14 \%)$ and 32/186 (17.2\%), respectively.

Table 1/ Total results of SICCT and IDEXX ELISA

\begin{tabular}{|c|c|c|c|c|c|}
\hline \multirow{2}{*}{ Test } & \multirow{2}{*}{ No. } & \multicolumn{2}{|c|}{ Positive } & \multicolumn{2}{c|}{ Negative } \\
\cline { 3 - 6 } & & No. & $\%$ & No. & $\%$ \\
\hline SICCT & 186 & 17 & $9^{\text {a }}{ }^{\mathrm{a}}$ & 169 & $\mathbf{9 0 . 8 6}$ \\
\hline ELISA & 186 & 32 & $10.2^{\mathrm{b}}$ & 154 & $\mathbf{8 2 . 8}$ \\
\hline
\end{tabular}

The different small letters had differences at level $\boldsymbol{P}<\mathbf{0 . 0 5}$

Although, several studies were done in Iraq by using different methods but, comparatively, the results were less than those recorded by this study and this variation could be attributed to several agents like the "herd size, density of animals, breeding and management system, uncontrolled animal movement, unhygienic local habits and stress factors due to other diseases and mass 
vaccination against various diseases "(27). The high positives results of IDEXX ELISA in compared with SICCT may refer to the high sensitivity rate of first test and inability of SICCT to detect the antibodies at all stages of disease's development or could be due the cross reaction of Mycobacterium spp. with SICCT $(28,29)$. In herds, where the control on infection is based on an identification and removal of reactors by using the tuberculin method, some diseased cattle with chronic phase or with unblock lesions, fail to reveal the reaction for PPD and, thus, could still in a farm as a latent provenance for disease in oversensitive cows (30). As well as, although the SICCT is valid method in cattle's group, but it's admitted that is restricted for using in detection the individualist diseased cattle. Also, it's a slowly method for gaining results because of the period that required for showing the interaction (31). In addition, many factors can lead to false-positive or falsenegative results such as the PPD antigen quality and manipulation, skin induration interpretation, and injection dose protocols (32, 33). Whilst, the major disadvantages of SICCT are an absence of specificity and increasing the numbers of no-visible-lesion reactors which occurs (34).

In depending on age groups (Table 2), cattle of less than five years group reported 6/119 (5.04\%) positives by SICCT and 14/119 (11.76\%) with IDEXX ELISA, whereas, in more than five years group, the SICCT and IDEXX ELISA tests were $11 / 67(16.41 \%)$ and $18 / 67(26.86 \%)$ positive cases, respectively.

Table 2 / Results of SICCT and IDEXX ELISA according to Age

\begin{tabular}{|c|c|c|c|c|}
\hline \multirow{2}{*}{ Test } & \multicolumn{2}{|c|}{ Positive cases in 119 cattle $<5$ Years } & \multicolumn{2}{c|}{ Positive cases in 67 cattle $>5$ Years } \\
\cline { 2 - 5 } & No. & $\%$ & No. & $\%$ \\
\hline SICCT & 6 & $5.04^{\mathrm{aA}}$ & 11 & $16.41^{\mathrm{ab}}$ \\
\hline ELISA & 14 & $11.76^{\mathrm{bA}}$ & 18 & $26.86^{\mathrm{bB}}$ \\
\hline
\end{tabular}

The small and large letters refers to vertical and horizontal significant differences, respectively, at level $\boldsymbol{P}<\mathbf{0 . 0 5}$

Both, SICCT \& IDEXX ELISA, tests reported that the increasing in BTB infection was directly proportional with age's progression, and reaching to maximum at 5-9 years. For cows, the age reliance risk factor has still to be quantified, although all age groups can be affected, because of the little information or finiteness of diagnostic methods $(34,35)$. The increasing of BTB expansion with cattle's age was reported in Ethiopia, Tanzania, Latvia, Ireland, United Kingdom, Canada and Mexico $(36,19,37)$. Mackay and Hein (1989) concluded that the influences of $\gamma-$ DT cells that found, mostly, in young calves' blood flow might be play a role in 
anti-mycobacterial immunity. Also, he proposed that the increasing in BTB incidence with aged cattle could interpreted as a result of reducing the defensive ability of these cows $(\mathbf{3 8}, \mathbf{3 9}, \mathbf{4 0})$. Kazwala et al. (2001), Cleaveland et al. (2007) and Cadmus et al. (2010) believed that the age, alone, hasn't an important sufficient value for disease's sensibility and the existing belief, in endemic situation, is that due to increasing the exposure's time for tuberculosis through advancing of age (41, 42, 43). Moreover, Phillips (2005) reported that the evidence of genetic variation in susceptibility of cattle to $M$. bovis infection, at least in families and genera, and susceptibility also increases with age (44). Barak (2012) recorded that the difference in results between age stages of cattle could be as a result of slow progression of the disease until reach to the detectable level (45). Francis et al. (1978) writes "The evidence suggests that even when young cattle are pastured with heavily infected old stock, the incidence in the former remains low until they enter the cow shed "(46).

Significantly, the results of (Table 3) didn't reveal any differences between both sexes and this agreement with those reported by $(\mathbf{4 7}, 42)$. In opposite, $(48,43)$ reported that the females being at greater risk for infection with $M$. bovis than males, while (35) showed that the males had more readiness for infection than females. Katale et al. (2013) reported that BTB incidence appear to be gain with age's advancing but only in females, particularly, in those cows over 4 years (37). McCrindle (2007) observed that, during controlling studies, there was no relationship between the sensitivity for acquiring the infection with sex of animal (49).

Table 2 / Results of SICCT and IDEXX ELISA according to Sex

\begin{tabular}{|c|c|c|c|c|}
\hline \multirow{2}{*}{ Test } & \multicolumn{2}{|c|}{ Positive cases in 155 Females } & \multicolumn{2}{c|}{ Positive cases in 31 Males } \\
\cline { 2 - 5 } & No. & $\%$ & No. & $\%$ \\
\hline SICCT & 14 & $9_{.03}^{\text {ab }}$ & 3 & $9.67^{\mathrm{aB}}$ \\
\hline ELISA & 27 & $17.41^{\mathrm{bB}}$ & 5 & $\mathbf{1 6 . 1 2}^{\mathrm{bB}}$ \\
\hline
\end{tabular}

The small and large letters refers to vertical and horizontal significant differences, respectively, at level $\boldsymbol{P}<\mathbf{0 . 0 5}$

In conclusion, IDEXX ELISA that licensed by OIE in 2012 was used for first time in Iraq as a new diagnostics for BTB in cattle. Its efficiently, can be used in detection, eradication and control programs as a rapid screening test, because the disease is still represents a public health hazard, and the efforts should be made to 
control on it. The lack of veterinary infrastructure that required for BTB surveillance may be the main cause for increasing the disease's incidence.

\section{Acknowledgment}

I wish to express my special thanks to assist lecture. Hasanain AJ. Al-gharban "Department of Internal and Preventive Medicine/ College of Veterinary Medicine/ Wasit University" and assist prof. Dr. Hams Al-Fattli / Department of Microbiology, College of Pharmacology, University of Al-Qadisiyah; for great help me during the study. 


\section{References}

1. Wirth, T.; Hildebrand, F.; Allix-Beguec, C.; Wolbeling, F.; Kubica, T.; Kremer, K.; Van Soolingen, D.; Rusch-Gerdens, S.; Locht, C.; Brisse, S.; Meyer, A.; Supply, P. and Niemann, S. (2008) Origin, spread and demography of the Mycobacterium tuberculosis complex. PLoS Pathog, 4: e1000160.

2. Hershberg, R., Lipatov, M., Small, PM., Sheffer, H.; Niemann, S., Homolka, S.; Roach, JC.; Feldman, MW. and Gagneux, S. (2008). High functional diversity in Mycobacterium tuberculosis driven by genetic drift and human demography. PLoS Biol, 6: e311.

3. Phillips, CJC. ; Foster, CRW. ; Morris, PA. and Teverson, R. (2003). The transmission of Mycobacterium bovis infection to cattle. Research in veterinary science, 74(1), 1-15.

4. De Lisle, GW. ; Bengis, RG. ; Schmitt, SM. and O'Brien, DJ. (2002). Tuberculosis in freeranging wildlife: detection, diagnosis and management. Revue scientifique et technique (International Office of Epizootics), 21(2), 317-334.

5. Cousins, DV. and Florisson, N. (2005). A review of tests available for use in the diagnosis of tuberculosis in non-bovine species. International Office of Epizootics, 24(3), 1039-1059.

6. Hasso, SA. (2004). Confirmed pathogens of cows and buffaloes in Iraq. Iraqi Journal of Veterinary Sciences, Vol.18, No.1 (1-14).

7. Pandey, GS. ; Hang'ombe, BM.; Mushabati, F. and Kataba, A. (2013). Prevalence of tuberculosis among southern Zambian cattle and isolation of Mycobacterium bovis in raw milk obtained from tuberculin positive cows. Veterinary World, 6(12), 986-991.

8. Steele, JH. (1995). Regional Report of neglected zoonotic diseases In: Mycobacterium bovis infection in animals and humans. State University Press, Ames, Iowa, 162-172.

9. Ritacco, V.; Torres, P.; Sequeira, MD.; Reniero, A.; De Kantor, IN.; Thoen, CO. and Gilsdorf, MJ. (2008). Bovine tuberculosis in Latin America and the Caribbean. Mycobacterium Bovis: Infections in Animals and Humans. 2nd Ed. Wiley Publishers, Hoboken, NJ, USA, 149-160.

10. Muller, B; Durr, S; Alonso, S; Hattendorf, J.; Laisse, CJ.; Parsons SD.; van Helden PD.; Zinsstag, J. (2013) Zoonotic Mycobacterium bovis-induced tuberculosis in humans. Emergency Infectious Disease 19: 899-908.

11. WHO (2013) Global Tuberculosis Report 2013. World Health Organization. Geneva, Switzerland.

12. Abdulsahib, SS.; Al-kazaz, AK. and Al-Faham, MA. (2015). Genotyping of Mycobacterium tuberculosis from Iraqis patients. Global Journal of Bio-Science and Biotechnology, 4 (3): 234238.

13. Latorre, I.; De Souza-Galvao, M.; Ruiz-Manzano, J.; Lacoma, A.; Prat, C.; Altet, N. and Domínguez, J. (2010). Evaluating the non-tuberculous mycobacteria effect in the tuberculosis infection diagnosis. European Respiratory Journal, 35(2), 338-342.

14. Claridge, J.; Diggle, P.; McCann, CM. ; Mulcahy, G.; Flynn, R.; McNair, J.; Strain, S.; Welsh, M.; Baylis, M. and Williams, DJ. (2012). Fasciola hepatica is associated with the failure to detect bovine tuberculosis in dairy cattle. Nature Communications 3, 853.

15. Hirpa, E.; Ameni, G.; Lawrence, JC. ; Tafess, K.; Worku, A.; Sori, T. and Zewdie, O. (2014). Performance Evaluation of Mycobacterium bovis Antibody Test for the Diagnosis of Bovine Tuberculosis in Ethiopia. System, 5, 9. 
16. Mudhar, ASA. (2015). Application of Tuberculin screening tests for determination the prevalence of bovine tuberculosis in Basra governorate /Iraq. Mirror of Research in Veterinary Sciences and Animals (MRVSA). 4 (3), 1-8.

17. Waters, WR. ; Whelan, AO. ; Lyashchenko, KP. ; Greenwald, R.; Palmer, MV. ; Harris, BN.; Hewinson, RG. and Vordermeier, HM. (2010). Immune responses in cattle inoculated with Mycobacterium bovis, Mycobacterium tuberculosis, or Mycobacterium kansasii. Clinical and Vaccine Immunology, 17(2), 247-252.

18. OIE, (2009). Office International des Epizooties Terrestrial manual, Manual of diagnostic tests and vaccines for terrestrial animals. Chapter 2.4.7, WHO for Animal Health, Paris.

19. Ameni, G. and Erkihun, A. (2007). Bovine tuberculosis on small-scale dairy farms in Adama Town, central Ethiopia, and farmer awareness of the disease. OIE, 26(3), 711-720.

20. Mukundan, H., Chambers, M., Waters, R. and Larsen, M. (2015). Tuberculosis, Leprosy and Mycobacterial Diseases of Man and Animals: The Many Hosts of Mycobacteria. CABI. Pp: 221-224.

21. OIE, (2012). Procedure for Registration of Diagnostic Kits Abstract sheet IDEXX M.bovis Antibody Test Kit, IDEXX Laboratories, www.oie.int.Accessed August /11/2012.

22. Weiss, DJ. and Wardrop, KJ. (2010). Normal Hematology of Cattle. Schalm's Vet. Hemat.. 2121 State Avenue, Ames, Iowa 50014-8300, USA. Pp: 829 - 835.

23. Schiller, I.; Oesch, B.; Vordermeier, HM.; Palmer, MV.; Harris, BN.; Orloski, KA. and Waters, WR. (2010). Bovine tuberculosis: a review of current and emerging diagnostic techniques in view of their relevance for disease control and eradication. Trans boundary and emerging diseases, 57(4), 205-220.

24. Onwuegbuzie, AJ. and Leech, NL. (2007). Sampling Designs in Qualitative Research: Making the Sampling Process More Public. Qualitative Report, 12(2), 238-254.

25. Hassanain, NA., Hassanain, MA., Soliman, YA., Ghazy, AA. and Ghazyi, YA. (2009). Bovine tuberculosis in a dairy cattle farm as a threat to public health. African Journal of Microbiology Research, 3(8), 446-450.

26. Burbelo, PD., Keller, J., Wagner, J., Klimavicz, JS., Bayat, A., Rhodes, CS., Holland, SM. (2015). Serological diagnosis of pulmonary Mycobacterium tuberculosis infection by LIPS using a multiple antigen mixture. BMC microbiology, 15(1), 205.

27. El-Mahrouk, AM. and El-Balawy, MB. (2010). Bacteriological, Serological, Molecular characterization and risk assessment of bovine tuberculosis in cattle. Egyp. J. Comp. Path. \& Clin. Path, 23(1), 164.

28. Aranaz, A.; Bezos, J.; Álvarez, J.; Romero, B.; Lozano, F.; Paramio, JL. and Domínguez, L. (2006). Assessment of diagnostic tools for eradication of bovine tuberculosis in cattle coinfected with M. bovis and M. avium subsp. paratuberculosis. Vet. Research, 37(4), 593-606.

29. Ngandolo, BN.; Müller, B.; Diguimbaye - Djaïbe, C.; Schiller, I.; Cagiola, M. and Zinsstag, J. (2009). Comparative assessment of fluorescence polarization and tuberculin skin testing for the diagnosis of bovine tuberculosis in Chadian cattle. Preventive vet. Med., 89(1), 81-89.

30. Diaz-Otero, F.; Banda-Ruiz, V.; Jaramillo-Meza, L; Arriaga-Diaz, C.; Gonzalez-Salazar, D. and Estrada-Chavez, C. (2003): Identification of Mycobacterium bovis infected cattle by immunological and molecular methods. Veterinaria-Mexico, 34 (1): 13-26.

31. Elsify, A.; Nayel, M.; Hazem, S.; Tarabess, R.; Akram, S.; Allaam, M.; Hassan, H. and ElGarhy, M. (2013). Sero-diagnosis of bovine tuberculosis by ELISA using bovine PPD and ST.CF. BS. VET. MED. J. $7^{\text {th }}$ SCI. CONF., 22 (1):126-129. 
32. Monaghan, ML.; Doherty, ML.; Collins, JD.; Kazda, JF. and Quinn, PJ. (1994). The tuberculin test. Veterinary microbiology, 40(1), 111-124.

33. Acosta, F.; Chernyaeva, E.; Mendoza, L.; Sambrano, D.; Correa, R.; Rotkevich, M.; Tarté, M.; Velazco, HH.; de Escobar, C.; de Waard, JH. and Goodridge, A. (2015). Mycobacterium bovis in Panama, 2013. Emerging infectious diseases, 21(6), 1059.

34. Radostits, OM.; Gay, CC.; Hinchcliff, KW. and Constable, PD. (2007). Veterinary Medicine: A textbook of the diseases of cattle, horses, sheep, pigs and goats. $10^{\text {th }}$ ed. Saunders Elsevier Company Ltd, London. Part 2, diseases associated with bacteria - IV, Pp: 1007-1017.

35. Brooks-Pollock, E.; Conlan, AJ.; Mitchell, AP.; Blackwell, R.; McKinley, TJ. and Wood, JL. (2013). Age-dependent patterns of bovine tuberculosis in cattle. Vet. Res, 44, 97.

36. Ward, AI.; Tolhurst, BA. and Delahay, RJ. (2006). Farm husbandry and the risks of disease transmission between wild and domestic mammals: a brief review focusing on bovine tuberculosis in badgers and cattle. Animal Science 82, 767-773.

37. Katale, BZ.; Mbugi, EV. ; Karimuribo, ED.; Keyyu, JD.; Kendall, S.; Kibiki, GS. and Matee, MI. (2013). Prevalence and risk factors for infection of bovine tuberculosis in indigenous cattle in the Serengeti ecosystem, Tanzania. BMC veterinary research, 9(1), 267.

38. Mackay, CR. and Hein, WR. (1989). A large proportion of bovine T cells express the $\gamma \mathrm{T}$ cell receptor and show a distinct tissue distribution and surface phenotype. Int. Immun., 1(5), 540545.

39. O'reilly, LM. and Daborn, CJ. (1995). The epidemiology of Mycobacterium bovis infections in animals and man: a review. Tubercle Lung Dis. (Supple.1), 76: 1-46.

40. Barwinek, F. and Taylor, NM. (1996). Assessment of the socio-economic importance of Bovine Tuberculosis in Turkey and possible strategies for control or eradication: Turkish-German animal health information project General Direktorate of Protection and Control, Ankara. GTZ. p. 3-45.

41. Kazwala, RR. ; Kambarage, DM. ; Daborn, CJ. ; Nyange, J.; Jiwa, SFH. and Sharp, JM. (2001). Risk factors associated with the occurrence of bovine tuberculosis in cattle in the Southern Highlands of Tanzania. Veterinary Research Communications, 25(8), 609-614.

42. Cleaveland, S.; Shaw, DJ. ; Mfinanga, SG. ; Shirima, G.; Kazwala, RR. ; Eblate, E. and Sharp, M. (2007). Mycobacterium bovis in rural Tanzania: risk factors for infection in human and cattle populations. Tuberculosis, 87(1), 30-43.

43. Cadmus, SI.; Agada, CA.; Onoja, II. and Salisu, I. (2010). Risk factors associated with bovine tuberculosis in some selected herds in Nigeria. Tropical animal health and production, 42(4), 547-549.

44. Phillips, JC. (2005). Focus on Tuberculosis Research. The Epidemiology and Control of Bovine Tuberculosis. Nova Science Publishers Ltd, School of Veterinary Science Publications, pp: 203-247.

45. Barak, SS. (2012). The incidence of bovine tuberculosis \& its public health hazards in a dairy cattle station in Iraq. Al-Anbar Journal veterinary Science, 5(2), 23-26.

46. Francis, J.; Seiler, RJ. ; Wilkie, IW. ; O'Boyle, D.; Lumsden, MJ. and Frost, AJ. (1978). The sensitivity and specificity of various tuberculin tests using bovine PPD and other tuberculins. Vet Rec 103, 420-5.

47. Asiak, I.; Ohore, O.; Emikpe, B.; Abatan, O. and Ockiya, M. (2007). The use of ELIZA for the detection of bovine tuberculosis in slaughtered trade cattle and sedentary herds in South West Nigeria. J. Anim. Vet. Adv. 6: 883-886. 
48. Inangolet, FO. ; Demelash, B.; Oloya, J.; Opuda-Asibo, J. and Skjerve, E. (2008). A crosssectional study of bovine tuberculosis in the transhumant and agro-pastoral cattle herds in the border areas of Katakwi and Moroto districts, Uganda. Tropical animal health and production, 40(7), 501-508.

49. McCrindle, CM. and Michel, A. (2007). Status for controlling bovine tuberculosis in Africa. Bulletin - International Dairy Federation, 416, 95. 